УДК 581.9:631.48

doi: $10.31251 /$ pos.v1i4.47

Check for updates

\title{
ФОРМИРОВАНИЕ ГУМУСОВОГО ПРОФИЛЯ ПОЧВ В ДЛИТЕЛЬНО-ПРОИЗВОДНЫХ ЛЕСАХ ВАСЮГАНСКОЙ РАВНИНЫ (ЗАПАДНАЯ СИБИРЬ)
}

\author{
(C) 2018 Н.В. Климова, А.Г. Дюкарев
}

Адрес: ФГБУН Институт мониторинга климатических и экологических систем СО РАН, Академический проспект 10/3, г.Томск, 634055, Россия.E-mail:klimnin@sibmail.com

\begin{abstract}
Цель исследования. Выявить особенности формирования и голоченовой эволючии гумусового профиля почв в длительно-прочзводных лесах Васюганской равнины.

Место и время проведения. Васюганская равнина, иентральная часть южно-таёжной подзоны на территории Обь-Иртышского междуречья. Березняки травяные (разнотравно-осочковые, осокововейниковые). Приведень результаты многолетних исследований.

Методология. Комплексные исследования почвенного и растительного покрова, палеогеографические реконструкиии на основе анализа фракиионного состава гумуса $и$ микробиоморфных спектров.

Основные результаты. В современных почвах Васюганской равнины выявлены признаки характерные для ландиафтов более южных территорий: повышенная продуктивность напочвенного покрова $u$ соответственно активность гумусово-аккумулятивных процессов. По данным анализа фракционного состава гумуса и микробиоморфного анализа современного и реликтового гумусового горизонта выявлено, что в разные климатические эпохи голочена на Васюганской равнине формировались схожие растительные сообщества - высокопродуктивные лиственные леса, обеспечивающие в разной степени сохранность реликтовых гумусовых горизонтов почв.

Заключение. Выявленные в почвах и растительных сообществах исследованных лесов южные черты связаны не только со сменой климатических условий, но и карбонатностью почвообразующих пород, обеспечивающих замедление восстановительных циклов коренной растительности на стадии травяных лиственных лесов. Выявленное сходство фитолитных комплексов современных и реликтовых гумусовых горизонтов при различиях во фракиионном составе гумуса отражает относительную устойчивость травяных березняков к климатическим колебаниям и подчеркивает маятниковую эволюцию гумусовых горизонтов с различным сочетанием продолжительности этапов их деградации и проградацฺии.
\end{abstract}

Ключевые слова: Васюганская равнина; длительно-производные леса; современные и реликтовые гумусовые горизонты; микробиоморфный анализ; фракционный состав гумуса; эволющия почв.

Цитирование: Климова Н.В., Дюкарев А.Г. Формирование гумусового профиля почв в длительнопроизводных лесах Васюганской равнины // Почвы и окружающая среда. 2018. № 1(4). С.218 -230.

\section{ВВЕДЕНИЕ}

Одной из важных проблем в почвоведении остается объяснение происхождения почв со сложным строением гумусового профиля, включающего как современный, так и реликтовый горизонт. История изучения «второго», а по своей сути первого гумусового горизонта связана с началом исследований почвенного покрова Западной Сибири. Именно на юге таёжной зоны, а точнее на территории современной Васюганской равнины, первыми исследователями (А.Я. Гордягин, Д.А. Драницын, Р.С. Ильин, А.В. Отрыганьев) отмечен феномен присутствия в почвенном профиле «вторых» гумусовых горизонтов. В дальнейшем ареал распространения почв со вторым гумусовым горизонтом расширен на всю территорию бореальных и суббореальных лесов. Именно эти исследования послужили основанием гипотезы изменения климата, растительных и ландшафтных границ. Обзоры исследований генезиса и эволюции почв со вторым гумусовым горизонтом широко известны и достаточно полно представлены ранее (Гаджиев, 1982; Дюкарев, 2005). Из предложенных к настоящему времени гипотез, как для территории Западной Сибири, так и сопредельных территорий Восточно-Европейской равнины (Александровский, 1983) наиболее обосновано предположение о реликтовой природе вторых гумусовых горизонтов, в котором они рассматриваются как нижние, сохранившиеся части более мощных органопрофилей почв, сформировавшихся на исследованной территории ранее, в теплых и влажных условиях атлантического оптимума голоцена. Однако основные исследования в этом направлении проведены на почвах под зональными темнохвойными лесами (Гаджиев, 1982; Гаврилов, 2016), и 
мало внимания уделено лиственным лесам, являющимся на суглинистых отложениях Васюганской равнины непременным атрибутом восстановительной динамики зональной растительности. Между тем, развитие их, вероятно, подчиняется другим закономерностям, поскольку на современном этапе эти леса относятся к длительно-производным - восстановление темнохвойного полога в них подавляется густым травяным покровом, что связано с карбонатностью почвообразующих пород, возможно, и с осолодением почв, и высокой гидроморфностью территории (Уфимцева 1974; Дюкарев, Пологова, 2011). Почвообразование здесь отличается от почвообразования под типичными для южной тайги темнохвойными лесами и протекает в условиях более высокой биологической активности, поступления на поверхность растительного опада, отличающегося как по количественным, так и качественным характеристикам. В настоящее время более половины лесопокрытой площади южнотаежной подзоны Западной Сибири приходится на лиственные осиновые и большей частью березовые леса (Бех, 1992), то же наблюдается и на юге Васюганской равнины (Храмов, Валуцкий 1977). К сохранившимся на приподнятых дренированных поверхностях коренным лесам здесь приурочены дерновые оподзоленные и дерново-подзолистые остаточно-гумусовые (со вторым гумусовым горизонтом) почвы. А с длительно-производными лиственными лесами связаны в своем распространении почвы со сложным строением гумусового профиля (органо-аккумулятивные темно- и серо-гумусовые) с высокой активностью современного и сохранностью признаков реликтового гумусонакопления. Формирование их объясняется не только цикличностью климата в голоцене, но и естественной биологической цикличностью развития лесных экосистем на ландшафтно-геохимических границах - на юге лесной зоны, где условия для произрастания древесных видов становятся напряженными (Лащинский, 2009), взаимосвязи между почвенным и растительным компонентами ландшафта нарушаются, признаки климатической зональности в почвенном и растительном покрове приобретают островной характер.

Исследования проведены с целью выявления особенностей формирования сложного по строению гумусового профиля почв в циклах восстановительно-возрастной динамики лесов на ландшафтно-геохимических границах Васюганской равнины (Западная Сибирь, южная тайга).

\section{МАТЕРИАЛЫ И МЕТОДЫ ИССЛЕДОВАНИЯ}

Исследования по выявлению значимости длительно-производных лиственных лесов в генезисе остаточно-гумусовых (со вторым горизонтом) почв проведены на территории Васюганской равнины (рис. 1), сложенной карбонатными глинами и суглинками. Некоторыми исследователями отмечается солонцеватость отложений, что связывается с ее примыканием к сложенной засоленными грунтами Барабинской равнине (Ильин, 1930; Казанцев, 1998). В условиях плоского рельефа, превышения количества осадков над испарением, низкой водопроницаемости почвообразующих пород, слабой дренирующей способности рек, почвенногрунтовые и грунтовые воды повсеместно встречаются на глубине не более 3 м, и постоянно подпитываются водами, стекающими с обширных водораздельных болот (Ружанский, 1972).

Растительный и почвенный покров весьма неоднородный и определяется удаленностью от болотного массива, локальных условий дренированности и выщелоченности почвообразующих пород. В почвенном покрове господствуют гидроморфные, с различной мощностью торфяных отложений, и полугидроморфные органо-аккумулятивные почвы с различной сохранностью палеогумусовых горизонтов. На дренированных поверхностях формируются органоаккумулятивные дерновые оподзоленные, реже дерново-подзолистые остаточно-гумусовые высоковскипающие почвы (Дюкарев, Пологова, 2011). И те, и другие в своем распространении тесно связаны с лиственными травяными лесными сообществами, находящимися на разных стадиях восстановления коренных темнохвойных лесов. Реликтовая часть гумусового профиля выделяется во всех исследованных почвах. Радиоуглеродный возраст реликтового горизонта, определенного по гуминовым кислотам, варьирует от 4 до 6 тыс. лет (Гаджиев, 1982). Степень его сохранности варьирует от темно-серого, почти черного, сливающегося по окраске с современным, горизонтом, до сероватых пятен в элювиальной части и гумусовых потеков в верхней части иллювиального профиля. Чем выше дренированность местоположений, тем интенсивнее трансформация гумусового горизонта и степень элювиально-иллювиальной дифференциации профиля, выщелоченность карбонатов. Мощность элювиальной части профиля на всех этапах эволюции в целом соответствует исходной мощности гумусового горизонта (Дюкарев, 2005). 
Признаки реликтового гумусонакопления в виде отдельных пятен и сероватых тонов окраски дольше всего сохраняются в нижней части элювиального профиля.

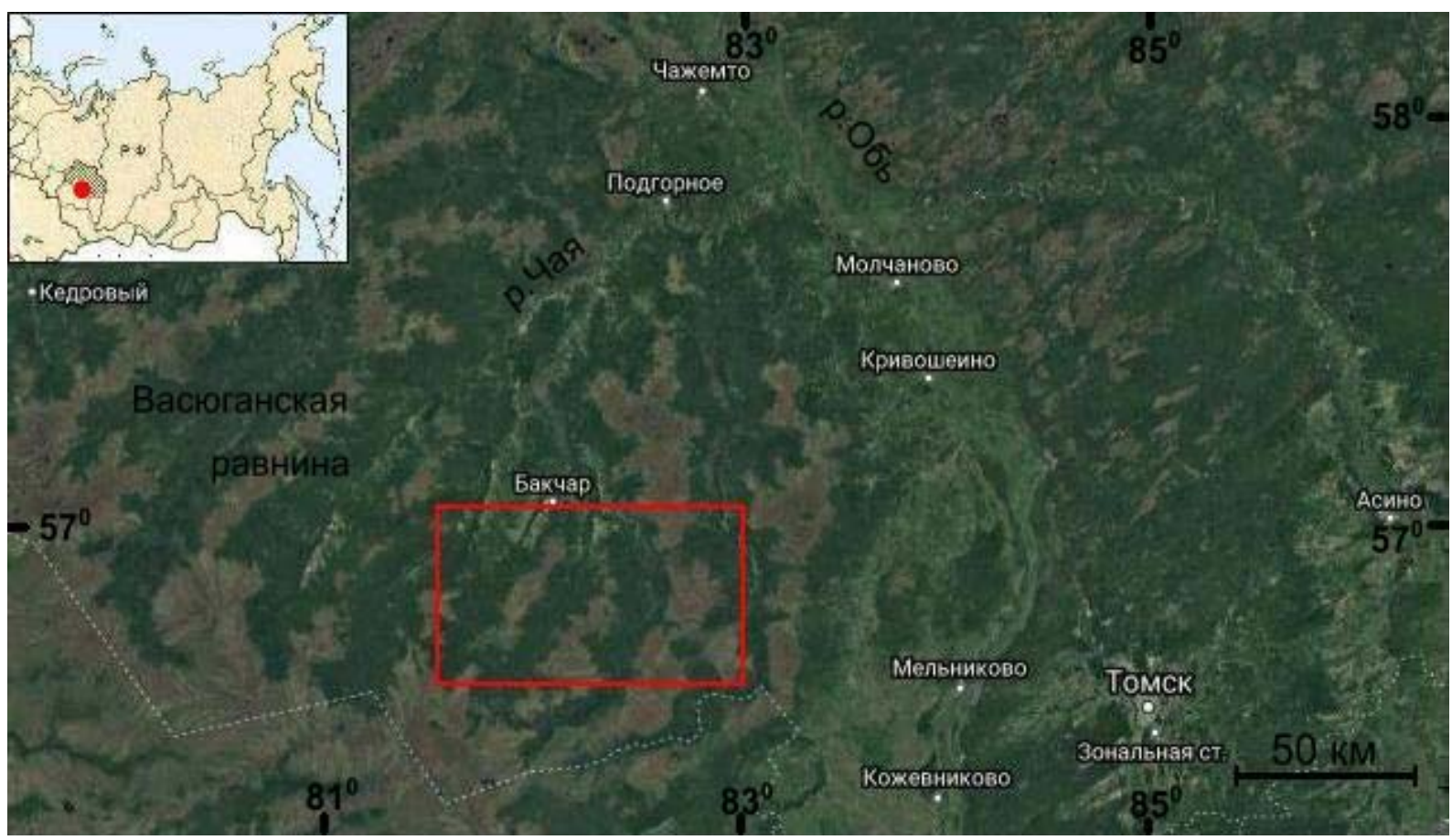

Рисунок 1. Карта района исследований (использован фрагмент космоснимка с сайта https://www.google.com/maps).

Обобщенная схема строения профиля органо-аккумулятивных почв представляется следующим образом: дерновый горизонт мощностью до 10 см (Aw), серогумусовый горизонт (АY) мощностью 15-30 см под которым залегает хорошо оструктуренный темногумусовый горизонт (AU) или реликтовый остаточно-гумусовый (Ahh) горизонт с нижней границей на глубине 3545 см. Переходный к почвообразующей породе горизонт только в оподзоленных почвах несет признаки иллювиирования (Bi). Чаще выделяется гидрометаморфический (Q) горизонт или горизонт с признаками метаморфизма $(\mathrm{Bm})$. Глубина залегания карбонатов варьирует в нешироких пределах: от 65 до 85 см. Почвы крайнего элювиального ряда, несмотря на то, что глубина выщелачивания карбонатов существенно не меняется, по морфологическим признакам близки к дерново-подзолистым. В иллювиальной части профиля здесь отмечается высокая потечность гумуса. Толщина гумусовых пленок на стенках трещин достигает 2-3 мм. Мощность же собственно текстурного горизонта невелика и составляет 35-45 см (Дюкарев, Пологова, 2011).
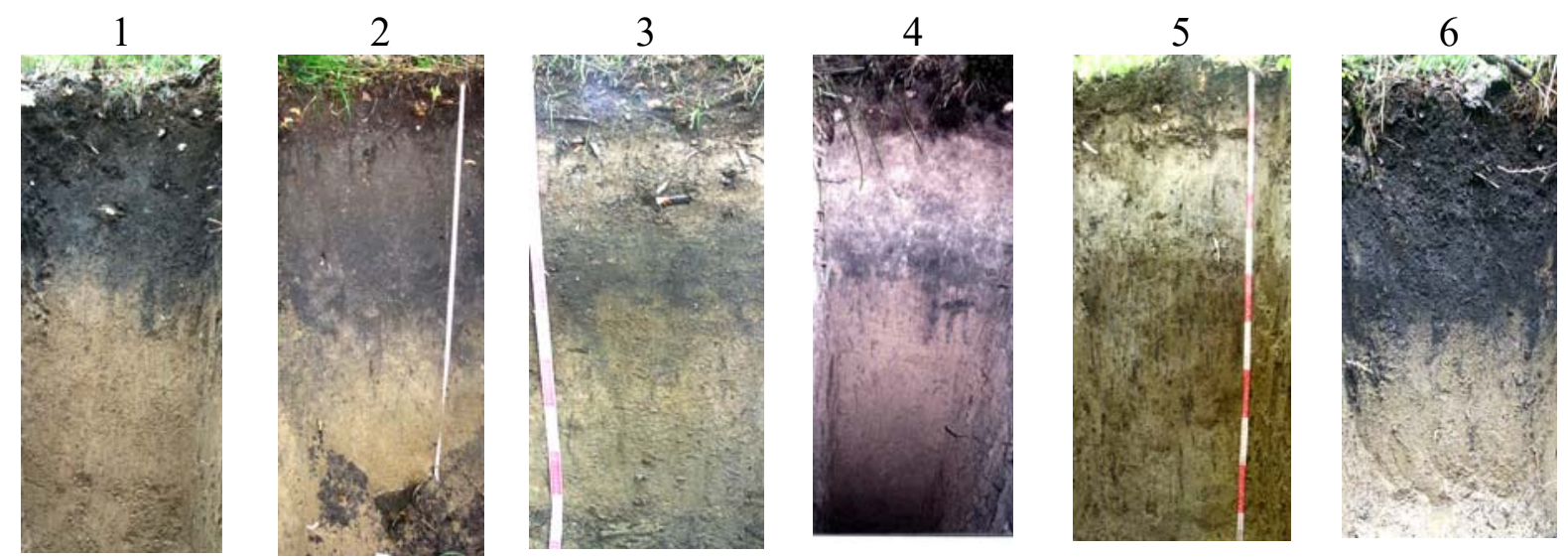

Рисунок 2. Основные типы почв южной тайги со сложным строением гумусового профиля. Обозначения в тексте. 
В элювиальном ряду органо-аккумулятивных почв, формирующихся на карбонатных глинах в центральной части Обь-Иртышского междуречья, нами исследованы (рис. 2):

1 - органо-аккумулятивные темно-гумусовые (AW-AU-Auh-Cca);

2 - органо-аккумулятивные типичные остаточно-гумусовые (AW-AY-Auh-Cca);

3 - органо-аккумулятивные оподзоленные остаточно-гумусовые (AW-AY-Ael-Auh-Bm-Cca);

4 - дерново-подзолистые остаточно-гумусовые (AW-AEL-EL-AUh-Bt-Cca);

5 - дерново-подзолистые потечно-гумусовые (AW-EL-BThi-Cca)

Для сравнения в качестве аналога тех почв, которые, согласно гипотезе о происхождении реликтовых гумусовых горизонтов (Гаджиев, 1982; Дюкарев, 2005), формировались в атлантическом периоде голоцена, исследованы

6 - гумусово-гидрометаморфические почвы подтайги.

Классификация почв и горизонтов дана в соответствии с классификацией почв России 2004 года (Классификация ..., 2004; Дюкарев, Пологова, 2011).

К органо-аккумулятивным почвам приурочены лиственные травяные леса. При сомкнутом древостое из осины (Populus tremula) и березы пушистой (Betula pubescens) высотой 22-25 м, диаметром 25-35 см, подрост в них очень редкий (до 500 экз/га), из темнохвойных и лиственных видов высотой 2-4(7) м, что позволяет относить эти сообщества к длительно-производным. Подлесок хорошо развит (5-25\%), травяной ярус густой (45-95\%). В соответствии со сводкой (Лащинский, Королюк, 2015), по флористическому составу эти сообщества - южнотаежные: основу их составляют виды, дифференцирующие южнотаежные леса (Caragana arborescens, Rosa acicularis, Sorbus sibirica, Carex macroura, Calamagrostis obtusata, Stellaria bungeana), значительное участие принимают виды общие для южнотаежных и подтаежных лесов (Padus avium, Rubus idaeus, Aegopodium podagraria, Rubus saxatilis, Pulmonaria mollis). На дерново-подзолистых почвах развиты темнохвойные травяные леса (Храмов, Валуцкий, 1977; Лащинский, Королюк, 2015). Древесный полог в них слагают пихта (Abies sibirica), кедр (Pinus sibirica) и ель (Picea obovata) с участием березы и осины. В подросте (до 8 тысяч экз/га) представлены те же виды, преобладает пихта. Подлесок из Sorbus sibirica, Rubus idaeus, Ribes spicatum, Padus avium, Caragana arborescens и др. Основу густого (до 70 \%) травяного яруса составляют Carex macroura, Calamagrostis obtusata, Oxalis acetosella, Stellaria bungeana, Dryopteris carthusiana, Equisetum pratense и др. Мхи не образуют сплошного покрова и приурочены в основном к старым валежинам (Hylocomium splendens, Pleurozium schreberi, Rhytidiadelphus triquetrus). Полугидроморфные экотопы с перегнойно-органо-аккумулятивными почвами заняты лиственными лесами с признаками начального заболачивания. Древостой в них, как и в автоморфных местообитаниях, - из березы и осины. Подрост - редкий, с участием кедра и ели. Напочвенный покров густой (45-70 \%), в нем доминируют более влаголюбивые виды - Calamagrostis phragmitoides с участием осок Carex globularis, C. canescens, C. vaginata и трав Filipendula ulmaria, Equisetum sylvaticum и др. Моховой покров (3-30 \%) представлен лесоболотными видами (Plagiomnium ellipticum, Calliergon cordifolium, Climacium dendroides, Sphagnum squarrosum).

Оценку химических и физических параметров почв проводили общепринятыми в почвоведении методами. Для изучения фракционного состава гумуса использовали метод И.В. Тюрина в модификации В.В. Пономаревой, Т.А. Плотниковой (1975). Подготовка почв для микробиоморфного анализа проведена по стандартной методике (Гольева, 2001). Микробиоморфная фракция в исследованных почвах представлена главным образом растительным детритом и фитолитами. Идентификацию фитолитов проводили в соответствии с экологической классификацией морфотипов А.А. Гольевой (2001).

\section{РЕЗУЛЬТАТЫ ИССЛЕДОВАНИЯ}

Исследование органо-аккумулятивных почв Васюганской равнины показало, что общими для них являются слабая по сравнению с типичными дерново-подзолистыми почвами дифференциация по гранулометрическому составу и хорошая оструктуренность гумусовых горизонтов. Главным отличием является сложное строение гумусового профиля, что определяется их положением в пространственно-временном ряду между почвами северной лесостепи и дерновоподзолистыми почвами южной тайги. На южных границах ареала органо-аккумулятивные почвы имеют мощный (до 50 см) гумусово-аккумулятивный горизонт темно-серого или даже черного цвета (AU), с высоким (6-8 \%) содержанием гумуса (рис. 3). К северным границам ареала под влиянием кислых лесных подстилок происходит деградация темно-гумусового горизонта и 
формирование на его месте буровато-серого (AY) горизонта типично таежного облика с содержанием гумуса 4-6 \%. Реликтовые (вторые) гумусовые горизонты в темно-гумусовых, и особенно в гумусово-гидрометаморфических почвах сливаются с современным горизонтом и обнаруживаются только при определении возраста и по свойствам органического вещества. В дерновых органо-аккумулятивных почвах реликтовый горизонт проявляется по более темной, чем в современном горизонте, окраске и агрегированности. Содержание гумуса в нем, несмотря на темный цвет, редко превышает 2 \% (рис 3). В дерновых оподзоленных и дерново-подзолистых почвах реликтовый горизонт выделяется фрагментарно, однако ясно прослеживаются признаки потечного гумуса в иллювиальной части профиля в виде натечных образований на поверхности агрегатов. Мощность гумусовых пленок на вертикальных стенках трещин достигает 2-3 мм, а проникают они на всю глубину иллювиального горизонта. Нижняя граница элювиальногумусового профиля, независимо от положения в классификационном ряду почв, залегает на глубине 45-55 см. По сравнению с типичными для южной тайги дерново-подзолистыми почвами, органо-аккумулятивные почвы отличаются более равномерным профильным распределением гумуса и резко выраженной нижней границей гумусового горизонта.

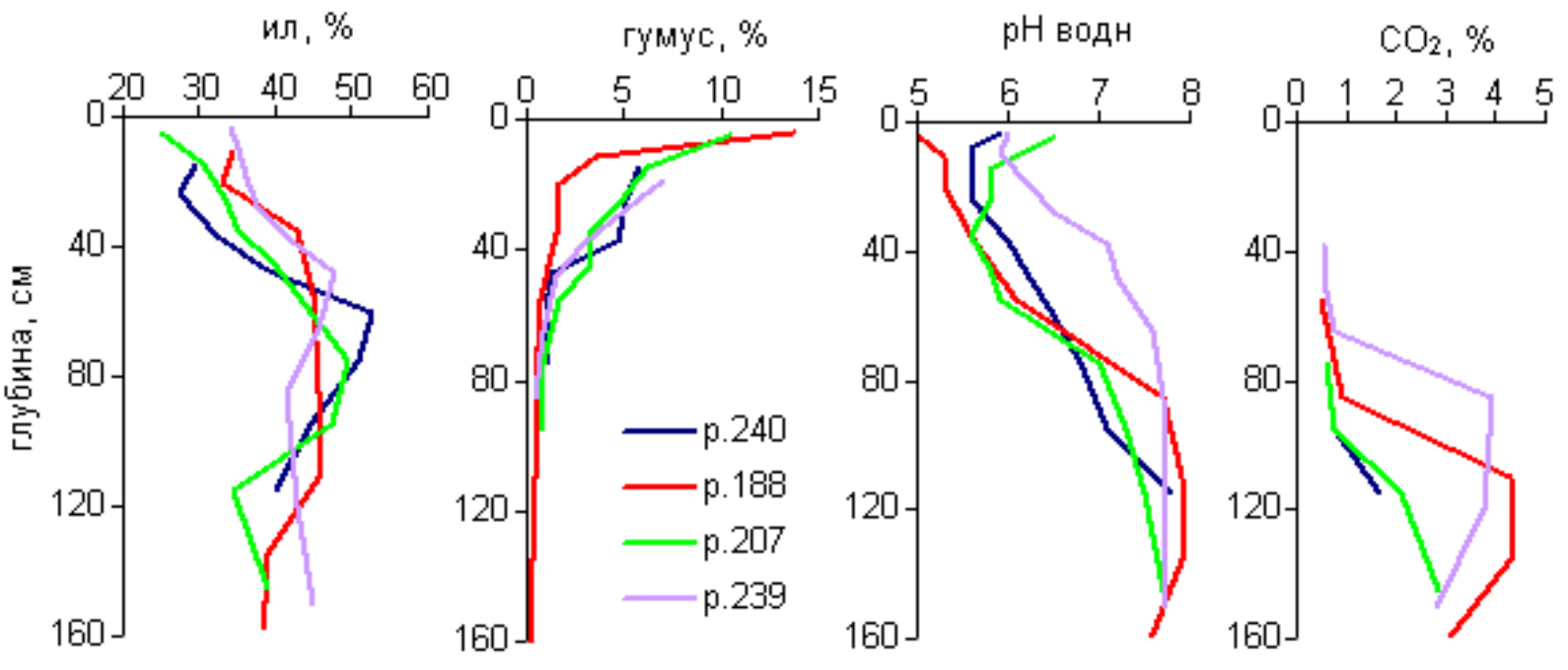

Рисунок 3. Свойства органо-аккумулятивных остаточно-гумусовых почв южной тайги Западной Сибири. Почвы: р. 240 - дерновая органо-аккумулятивная оподзоленная; p. 188 - дерновая органоаккумулятивная; р. 207 - темно-гумусовая органо-аккумулятивная; p. 239 -гумусовогидрометаморфическая

Отмечена высокая контрастность органо-аккумулятивных почв по кислотно-щелочным свойствам: слабокислая реакция в подподстилочных горизонтах, нейтральная в гумусовых и слабощелочная в подгумусовой части (рис. 3). Глубина выщелачивания карбонатов варьирует в нешироких пределах: от 65 до 85 см. Это связано с высокой карбонатностью и тяжелым грануметрическим составом почвообразующих пород. Специфической особенностью почв является присутствие в почвенно-поглощающем комплексе (ППК) одновалентных катионов К и $\mathrm{Na}$, что было отмечено еще К.А. Уфимцевой (1974). Даже незначительное содержание (2-4 \% от ППК) приводит к проявлению процессов слитизации гумусового горизонта при переменном увлажнении и потечности гумуса, ухудшает технологические свойства почв.

Близкое залегание карбонатов и солонцеватость почвообразующих пород обеспечивают высокую насыщенность ППК основаниями, предотвращает глубокую деградацию гумусового профиля. Трансформации подвергается только самая верхняя часть гумусового горизонта, испытывающая действие кислых продуктов распада лесных подстилок. Под подстилкой формируется, как правило, осветленный гумусовый (AY) горизонт мощностью до 15 см. Ниже сохраняется темный гумусовый (Au) горизонт. Принципиальных изменений гранулометрического состава не происходит. Однако в условиях высокой насыщенности ППК натрием и калием, при нарастании увлажнения происходит диспергация и переагрегация почв. В темных гумусовых горизонтах ухудшаются фильтрационные свойства и водно-воздушный режим. Они становятся водоупором, обеспечивающим переход почвы в новое качественное состояние - из полугидроморфной (заболоченной) в гидроморфную (болотную) (Дюкарев, Пологова, 2011). 
Свойства гумусовых профилей тесно связаны с составом и продуктивностью растительных сообществ. Так, в производных лиственных лесах продуктивность травяного яруса составляет 30 56 ц/га (в абсолютно-сухом состоянии). По сравнению с коренными лесами, основу опада составляют не хвоя, а листья, меньше участие мхов и значительно больше - трав. Формируется травяно-древесная по составу подстилка мощностью до 5 см, массой 118-164 ц/га. В полугидроморфных условиях ложбин и понижений продуктивность травяного яруса лиственных лесов составляет 23-34 ц/га. Состав опада тоже травяно-древесный. Однако здесь в условиях повышенного поверхностного увлажнения, связанного с разгрузкой вод со стороны водораздельных болот, минерализация опада замедлена, что ведет к формированию более мощных (до 10 см) подстилок массой 163-183 ц/га, характеризующихся высокой зольностью (до 17 \%), а в гидроморфных условиях - оторфованного горизонта мощностью до $15 \mathrm{~cm}$.

Качественный состав гумуса отражает различия в генезисе гумусовых горизонтов. Современный горизонт дерновых оподзоленных почв формируется в соответствии с климатическими условиями юга таежной зоны и имеет фульватно-гуматный состав гумуса. В условиях воздействия продуктов распада кислых лесных подстилок под коренными темнохвойными лесами высока подвижность оксидов металлов, что объясняет и высокое содержание в почвах первой фракции гуминовых кислот (рис. 4, табл. 1). По этой же причине в современных гумусовых горизонтах низкое содержание фракций связанных с кальцием. Фульвокислоты имеют относительно равномерное распределение. Отношение Сгк/Сфк варьирует от 1,1 до 1,6. При нарастании увлажнения и развитии элювиальных процессов, подвижность гумуса возрастает, а в его составе уменьшается доля гуминовых кислот. Отношение Сгк/Сфк изменяется от $0,9-1,2$ в оподзоленных почвах до 1,2-1,5 в гидрогенно трансформированных. В темно-гумусовых типах повышается доля гуминовых кислот связанных $\mathrm{c} \mathrm{Ca}^{++}$и оксидами металлов при неизменном содержании фульвокислот. Отношение Сгк/Сфк более широкое $(1,6-$ 1,8). В составе гуминовых кислот преобладает первая, наиболее подвижная фракция.

Остаточно-гумусовые горизонты характеризуются повышенным содержанием гуминовых кислот, уменьшением доли агрессивных фульвокислот (фракции 1 и $1 \mathrm{a})$ и самым широким в профиле отношением Сгк/Сфк (более 2,0). Отмечено увеличение содержания фракций связанных с кальцием, как среди гуминовых, так и среди фульвокислот.
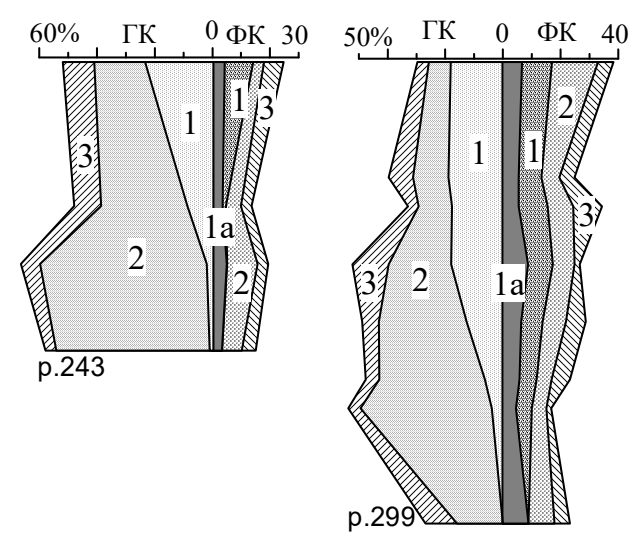
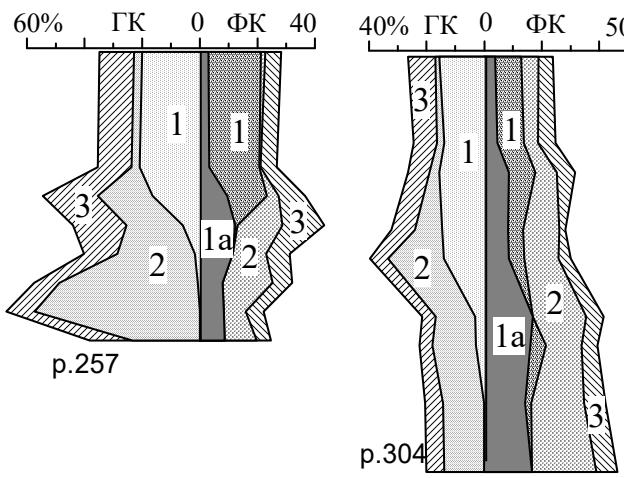

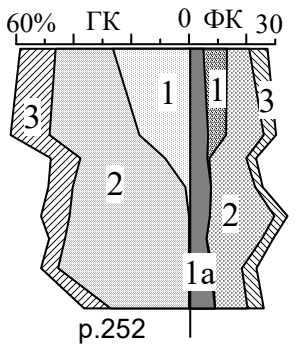

Рисунок 4. Состав гумуса исследованных почв. Обозначения почв как на рис. 3.

В фитолитных комплексах горизонтов современной активной аккумуляции гумуса преобладают формы двудольных трав и луговых злаков, меньше степных и лесных форм злаков, фитолиты хвойных не обнаружены (рис. 5). Варьирование состава напочвенного покрова соответствующих фитоценозов выражается главным образом в изменении доли степных форм злаков: в разнотравно-осочковых сообществах на северной границе ареала органоаккумулятивных почв она не превышает 5-7 \% (20\% форм злаков), а в разнотравно-злаковых сообществах на южной границе их ареала увеличивается до $15 \%$ (25 \% форм злаков). В фитолитных комплексах остаточно-гумусовых горизонтов наблюдаются в целом тот же набор и соотношение морфотипов кремниевых частиц. Выявленные комплексы очень близки к современному комплексу фитолитов гумусово-гидрометаморфической почвы, которая считается аналогичной почвам атлантического оптимума голоцена. 
Таблица 1. Основные показатели гумусного состояния почв

\begin{tabular}{|c|c|c|c|c|c|c|c|c|c|c|c|c|}
\hline \multirow{2}{*}{$\begin{array}{c}\text { Гори- } \\
\text { зонт }\end{array}$} & \multirow{2}{*}{$\begin{array}{c}\text { Глу- } \\
\text { бина, } \\
\text { см }\end{array}$} & \multirow{2}{*}{$\begin{array}{l}\mathrm{pH} \\
\text { вод. }\end{array}$} & $<0,01$ & $\begin{array}{c}\mathrm{CO}_{2} \\
\text { карб. }\end{array}$ & $\mathrm{C}_{\text {обш }}$ & Гк1 & Гк2 & Гк3 & Гк & $\begin{array}{c}\text { Фк- } \\
\text { 1a }\end{array}$ & \multirow{2}{*}{$\begin{array}{l}\mathrm{E}^{0,001 \% \mathrm{C}} \\
465 \text { нм 1см }\end{array}$} & \multirow{2}{*}{$\begin{array}{l}\text { Сгк/ } \\
\text { Сфк }\end{array}$} \\
\hline & & & \multicolumn{3}{|c|}{$\%$} & \multicolumn{3}{|c|}{ \% от суммы ГК } & \multicolumn{2}{|c|}{ \% от $\mathrm{C}_{\text {общ }}$} & & \\
\hline \multicolumn{13}{|c|}{ Органо-аккумулятивная темногумусовая насыщенная (5) } \\
\hline AW & 10 & 6.8 & 56.6 & 0.37 & 5.6 & 14 & 53' & 32" & $40 ”$ & 4 & & 1.53 \\
\hline $\mathrm{AU}$ & 23 & 7.2 & 60.6 & 0.34 & 4.2 & 6 & 70" & 25” & $38^{\prime}$ & 3 & & 2.17 \\
\hline $\mathrm{Au}$ & 41 & 7.4 & 65.5 & 0.36 & 1.9 & 2 & 80" & 17' & $45 "$ & 4 & & 2.81 \\
\hline \multicolumn{13}{|c|}{ Органо-аккумулятивная темногумусовая (n=7) } \\
\hline AW & 9 & 5.8 & 56.5 & - & 5.7 & 56 ' & 13 & 31" & 34.6 & 4 & $0.14 *$ & 1.12 \\
\hline $\mathrm{AU}$ & 25 & 6.2 & 61.9 & - & 3.8 & 46 ' & 37 & 17 & 42" & 6 , & 0.21 & 1.70 \\
\hline $\mathrm{Au}$ & 48 & 6.6 & 66.8 & 0.86 & 1.8 & 8 & $75 ”$ & $17^{\prime}$ & $51 " ”$ & $6^{\prime}$ & 0.25 & 2.17 \\
\hline \multicolumn{13}{|c|}{ Органо-аккумулятивная дерновая (серогумусовая) остаточно-гумусовая (n=5) } \\
\hline AW & 7 & 5.6 & & - & & & & & & & & \\
\hline AY & 29 & 5.5 & 60.9 & - & 2.9 & 45 , & 38 & 17 & 39 & 6' & $0.25^{*}$ & 1.41 \\
\hline $\mathrm{Au}$ & 50 & 5.9 & 64.0 & 0.93 & 1.8 & 12 & 79” & 9 & $51 "$ & 5 & 0.31 & 2.70 \\
\hline \multicolumn{13}{|c|}{ Органо-аккумулятивная оподзоленная остаточно-гумусовая (n=6) } \\
\hline AW & 12 & 5.3 & 57.9 & - & 7.2 & 59 & 9 & $32 "$ & 42” & 4 & $0.09 *$ & 1.45 \\
\hline $\mathrm{AYe}$ & 30 & 5.6 & 62.2 & - & 1.7 & 28 & 45 & $27 ”$ & 39' & 10 , & 0.15 & 1.15 \\
\hline $\mathrm{Au}$ & 44 & 6.1 & 67.8 & 0.81 & 1.2 & 20 & $65 ”$ & $15^{\prime}$ & 52"' & 9' & 0.26 & 1.95 \\
\hline \multicolumn{13}{|c|}{ Дерново-подзолистая остаточно-гумусовая $(\mathrm{n}=5)$} \\
\hline AV & 12 & 5.1 & 51.2 & - & 3.6 & 61" & 16 & 23" & $36^{\prime}$ & $6^{\prime}$ & & 1.26 \\
\hline AEL & 26 & 4.8 & 56.7 & - & 1.7 & 59' & 21 & 20' & $34^{\prime}$ & 13, & & 0.95 \\
\hline $\mathrm{Au}$ & 38 & 5.0 & 57.4 & - & 1.6 & 52 ' & 41 ' & 7 & 54"" & 7 & & 2.02 \\
\hline \multicolumn{13}{|c|}{ Дерново-подзолистая потечно-гумусовая (n=3) } \\
\hline AW & 8 & 5.2 & 51.2 & - & 3.9 & 54 & 10 & 36" & 26 & 5 & 0.20 & 1.08 \\
\hline $\mathrm{EL}$ & 25 & 4.9 & 54.1 & - & 1.6 & 52' & 14 & 33" & 22 & 9' & 0.16 & 0.79 \\
\hline $\mathrm{ELu}$ & 35 & 5.2 & 53.9 & - & 0.9 & 39 & 40 & $21^{\prime}$ & 36' & 8' & 0.42 & 1.23 \\
\hline \multicolumn{13}{|c|}{ Перегнойно-гумусовая гидрометаморфическая $(\mathrm{n}=3)$} \\
\hline HW & 20 & 6.1 & 56.4 & - & 9.5 & 36 & 42' & 22' & 60"” & 6 & 0.16 & 2.10 \\
\hline $\mathrm{AU}$ & 31 & 6.5 & 63.2 & 0.76 & 3.5 & 14 & 64" & 22' & 52"' & 6' & 0.21 & 1.91 \\
\hline $\mathrm{Au}$ & 47 & 7.0 & 68.5 & 0.75 & 1.7 & 1 & 88'"' & 11' & 57"' & 5 & 0.27 & 2.71 \\
\hline
\end{tabular}

Примечание: знаками показано, что характер признака и доля участия фракций гуминовых кислот оценивается как: ' - средняя; ”- высокая; "”- очень высокая. * текст.

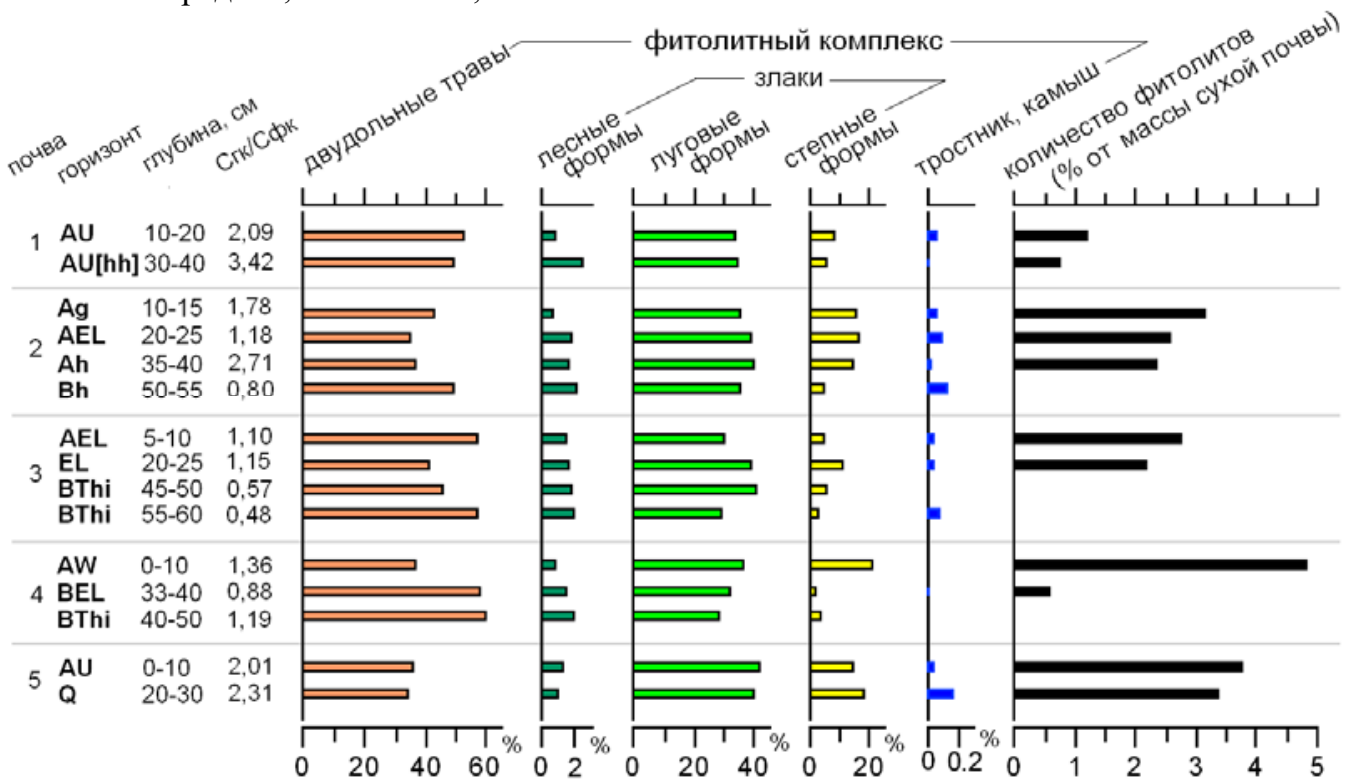

Рисунок 5. Содержание экологических групп морфотипов в фитолитных комплексах современных и реликтовых гумусовых горизонтов органо-аккумулятивной (1) и дерново-подзолистых остаточно-осолоделых (2-4) почв; а также в гумусово-гидрометаморфической почве - аналоге почв атлантического оптимума голоцена (5). 


\section{ОБСУЖДЕНИЕ}

Ландшафтная сущность почвообразования проявляется в том, что почва формируется и развивается вместе с ландшафтом. Поэтому каждому типу ландшафта соответствует определенный тип почвообразовательного процесса и почвенного профиля. Для почв, формирующихся на ландшафтно-геохимических границах при высокой динамичности климата, характерно сочетание в профиле разного типа почвообразовательных процессов. Здесь формируются сложные по строению почвенные профили.

Особенностью исследуемой территории является богатство почвообразующих пород, что сдерживает деградацию почв и растительности при изменении климата. При напряженных условиях нейтрального кальций-гумусового ландшафта на Васюганской равнине формируется весьма неоднородная структура почвенного и растительного покрова. На дренированных поверхностях, где карбонаты выщелочены глубже, формируются близкие к зональным типы леса с классической схемой лесоообразовательного процесса и элювиальным типом почвообразования. Признаки реликтового гумусонакопления здесь сохраняются слабо.

На слабодренированных территориях с неглубоко выщелоченными карбонатами и высоким уровнем увлажнения формируются почвы с высокой активностью процессов гумусонакопления. Повышенное содержание гумуса (до 6-8 \%), насыщенность ППК основаниями, слабокислая реакция, несвойственные зональным типам, сближают их с почвами более южных территорий. На основании этих признаков К.А. Уфимцева выделяла их в отдельную группу проградированных почв (1974). Их формирование во многом связано с тесным взаимодействием с приуроченными к ним растительными сообществами - травяными лиственными лесами. По сравнению с хвоей и мхами, листья и травы, составляющие основу опада в этих лесах, отличаются большей скоростью разложения, продукты распада менее кислые (Козловская с соавт, 1978; Гришина, 1986). Это определяет и менее кислую реакцию даже в верхних горизонтах органо-аккумулятивных почв, активизирует процессы гумусонакопления, препятствует развитию элювиальных процессов. В свою очередь, для формирующихся здесь фитоценозов отмечена высокая продуктивность травяного покрова, сравнимая с продуктивностью подтаежных растительных сообществ (Дюкарев и др., 2000; Ефремова, Ефремов, 2013; Титлянова, Шибарева, 2012). Мощные подстилки отличаются высокой зольностью и по свойствам близки к подстилкам эвтрофных болотных березняков (Ефремова и др., 2010). Хорошо развитый травяной покров с преобладанием густодерновинных видов (Carex macroura, Calamagrostis obtusata) препятствует восстановлению темнохвойного древесного полога подобно тому, как это происходит в длительно-производных сообществах подтайги (Лащинский, 2009). Избыточное увлажнение почв в гидроморфных местообитаниях также не способствует восстановлению коренной растительности. Таким образом, даже при недостатке тепла создаются условия для формирования продуктивных лесных сообществ характерных для более южных территорий. Этого достаточно для накопления на поверхности значительных объемов органического материала и стабильности гумусонакопления.

Как показывают исследования гумуса органо-аккумулятивных темно-гумусовых почв южной тайги и гумусово-гидрометаморфических почв подтайги, реликтовая часть гумусового профиля отличается от современной как по морфологическим, так и по химическим свойствам. Резко выраженная нижняя граница гумусового горизонта, большая доля гуминовых кислот в составе гумуса, увеличение содержания фракций, связанных с кальцием как среди гуминовых так и среди фульвокислот - признаки не характерные для южнотаежных дерново-подзолистых почв, указывающие на «лесостепное» происхождение реликтовых гумусовых горизонтов (Гаджиев, 1982; Караваева и др., 1985; Каллас, Кубрина, 2008). В то же время, фульватно-гуматный состав современного гумусового горизонта, как и южнотаежный состав фитоценозов, больше соответствует современным климатическим условиям. Тем не менее, на слабодренированных территориях, на всех этапах формирования почв сохранялись условия для высокой активности гумусообразования и распространения преимущественно лиственных лесов. Подтверждается это и исследованиями фитолитных комплексов гумусовых горизонтов, в которых отсутствуют формы, диагностирующие развитие темнохвойного леса. То же показывают реконструкции палинологическим методом (Бляхарчук, 2000), согласно которым 5 тысяч лет назад на Васюганской равнине были широко распространены березовые леса.

Все остальные экотопы занимают промежуточное положение в эволюционном ряду и в соответствии с ним различаются степенью развития элювиального почвообразования и 
сохранности реликтового гумусового горизонта. Следует отметить, что прослеживается связь между сохранностью реликтового гумусового горизонта и стадийностью лесообразовательного процесса. Чем больше растянут по времени лесовосстановительный процесс, тем выше сохранность реликтового гумусового горизонта. Это связано с сукцессионной динамикой почвообразования. На стадии коренных темнохвойных лесов, под кислыми лесными подстилками, идет деградация гумусового горизонта. На восстановительном этапе под травяными березовыми лесами идет активизация гумусонакопления и некоторое восстановление гумусового горизонта. Нами отмечено в травяных лесах активное проникновение корней в реликтовый горизонт. Следовательно, и здесь отмечается «подновление» и омоложение гумуса, что выявляется и при датировании южнотаежных почв по разным материалам (Гаврилов и др., 2017). Возможно, именно поэтому в длительно-производных лесах отмечена более высокая сохранность как современных, так и реликтовых гумусовых горизонтов. Таким образом, восстановительно-возрастная динамика лесных экосистем включает как этапы деградации почв, так и их восстановление. Такую цикличность мы отмечаем как маятниковую эволюцию почвообразования. Однако с учетом продолжительности восстановительного цикла в лесных экосистемах, особенно заметной на ландшафтно-геохимических границах, каждый последующий почвообразовательный цикл происходит в несколько иных ландшафтных, прежде всего климатических условиях. Чем продолжительнее этап восстановления (стадия лиственных лесов), тем более выражены как современный, так и реликтовый горизонты. В коренных лесах на глубоковыщелоченных породах стадия восстановления ограничивается только одним поколением лиственных лесов, поэтому проградация гумусового горизонта здесь практически незаметна - развивается в классическом виде элювиальное почвообразование.

\section{ЗАКЛЮЧЕНИЕ}

Исследование почв и растительности Васюганской равнины позволило выявить новые механизмы эволюции почв, связанные с динамикой лесообразовательного процесса. Продолжительность же этапа восстановления коренной темнохвойной растительности в свою очередь определяется почвенно-геохимическими условиями - богатством почв и выщелоченностью почвообразующих пород. Для сложенной карбонатными почвообразующими породами территории Васюганской равнины отмечается широкое распространение длительнопроизводных лиственных лесов, заметно отличающихся по составу и продуктивности от коренных темнохвойных, что замедляет процессы деградации как современных, так и реликтовых гумусовых горизонтов. Продолжительность восстановительного этапа лесообразовательного процесса с формированием травяных лиственных лесов и его соотношение с продолжительностью этапа зональных темнохвойных типов леса, определяет активность современного гумусонакопления, сохранность реликтового гумусового горизонта и элювиальную трансформированность профиля почв. Этот комплекс условий обусловливает относительную устойчивость этих сообществ к климатическим колебаниям. Эволюция же гумусового профиля приобретает маятниковый характер, в котором этапы деградации чередуются с восстановительными этапами. Размах колебаний и общее развитие почв связаны не только с изменениями климата, но и с соотношением продолжительности этапа восстановления коренных темнохвойных лесов. Полученные результаты подтверждают важность комплексного подхода с применением различных методов, что значительно расширяет возможности исследования, позволяя уточнять детали и выявлять дополнительные закономерности.

\section{БЛАГОДАРНОСТИ}

Работа проведена в рамках базового проекта СО РАН IX.135.1.3. «Экосистемные изменения в Сибири: локальные, региональные и глобальные аспекты».

\section{ЛИТЕРАТУРА}

1. Александровский А. Л. Эволюция почв Восточно-Европейской равнины в голоцене. М.: Наука, 1983.150 с.

2. Бех И.А. Антропогенная трансформация таежных лесов. Новосибирск: Наука, 1992. 200 с.

3. Бляхарчук T.A. История растительности юго-востока Западной Сибири в голоцене по данным ботанического и спорово-пыльцевого анализа торфа // Сибирский экологический журнал, 2000. Т.7. № 5. С. 659-668. 
4. Гаврилов Д.А. Генезис второго гумусового горизонта почв Васюганской наклонной равнины // Бюлл. Почв. ин-та им. В.В. Докучаева. 2016. Вып. 85. С. 3-19. doi: 10.19047/0136-1694-2016-85-5-19

5. Гаврилов Д.А., Лойко С.В., Лада Н.Ю., Климова Н.В. Радиоуглеродный возраст гумусово-элювиальной части полигенетичных почв южной тайги Западной Сибири // Почвенные ресурсы Сибири: вызовы XXI века. Сборник матер. Всерос. науч. конф. Новосибирск, 2017. С. 38-41.

6. Гаджиев И.М. Эволюция почв тайги Западной Сибири. Новосибирск: Наука, 1982. 278 с.

7. Гольева А.А. Фитолиты и их информационная роль в изучении природных и археологических объектов. M., $2001.200 \mathrm{c}$.

8. Гришина Л.А. Гумусообразование и гумусное состояние почв. М.: Изд-во МГУ, 1986. 244 с.

9. Дюкарев А.Г. Ландшафтно-динамические аспекты таежного почвообразования в Западной Сибири. Томск: Изд-во НТЛ, 2005. 284 с.

10. Дюкарев А.Г., Пологова Н.Н. Почвы Васюганской равнины со сложным органопрофилем // Почвоведение. 2011. № 5. С. 525-538.

11. Дюкарев А.Г., Пологова Н.Н., Мульдияров Е.Я. Луговое почвообразование в подтайге Западной Сибири // Почвоведение. 2000. № 9. С. 1064-1069.

12. Ефремова T.T., Ефремов С.П. Природа кислотных свойств подстилки болотных березняков // Журнал Сибирского федерального университета. Биология. 2013. № 2. С. 205-219.

13. Ефремова Т.Т., Ефремов С.П., Аврова А.Ф. О сопряженности морфогенетических типов подстилок с их свойствами в болотных березняках // Почвоведение. 2010. № 8. С. 920-928.

14. Ильин Р.С. Природа Нарымского края // Материалы по изучению Сибири. Томск, 1930. Т. II. 344 c.

15. Казанцев B.A. Проблемы педогалогенеза. Новосибирск: Наука, 1998. 280 с.

16. Каллас E.В., Кубрина Е.В. Специфика гумусового профиля лугово-черноземных почв южной тайги Западной Сибири // Вестник Томского государственного университета. Биология. 2008. №1. С. 63-70.

17. Караваева Н.А., Соколова Т.А., Целищева Л.К. Почвообразовательные процессы и эволюция гидрогенных почв подтайги - южной тайги в голоцене // Процессы почвообразования и эволющия почв. М.: Наука, 1985. с. 139-201.

18. Классификаиия и диагностиак почв России / Авторы и составители: Л.Л. Шишов, В.Д. Тонконогов, И.И. Лебедева, М.И. Герасимова. Смоленск: Ойкумена, 2004. 342 с.

19. Козловская Л.С., Медведева В.М., Пьявченко Н.И. Динамика органического вещества в процессе торфообразования. Л.: Наука, $1978.176 \mathrm{c.}$

20. Лащинский Н.Н. Растительность Салаирского кряжа. Новосибирск: Гео, 2009. 263 с.

21. Лащинский Н.Н., Королюк А.Ю. Синтаксономия темнохвойных зональных лесов южной тайги ЗападноСибирской равнины и гумидных низкогорий Алтае-Саянской горной области // Растительность России. 2015. № 26. С. 85-107.

22. Пономарева В.В., Плотникова Т.A. Методические указания по определению содержания и состава гумуса в почвах (минеральных и торфяных). Л., 1975. 105 с.

23. Ружанский В.В. Гидрогеологические условия // Природные условия освоения междуречья Обь-Иртыш. M., 1972. C. 32-36.

24. Титлянова А.А., Шибарева С.В. Подстилки в лесных и травяных экосистемах. Новосибирск: Изд-во СО $\mathrm{PAH}, 2012.137 \mathrm{c}$.

25. Уфимиева К.А. Почвы южной части таежной зоны Западно-Сибирской равнины. М.: Колос, 1974. $202 \mathrm{c}$. 26. Храмов А.А., Валуцкий В.И. Лесные и болотные фитоценозы Восточного Васюганья. Новосибирск: Наука, 1977. 222 с.

Поступила в редакиию 07.11.2018

Принята 13.12.2018

Опубликована 26.12.2018

Сведения об авторах:

Климова Нина Владимировна - младший научный сотрудник лаборатории мониторинга лесных экосистем Института мониторинга климатических и экологических систем СО РАН (Томск, Россия); klimnin@sibmail.com

Дюкарев Анатолий Григорьевич - доктор географических наук, заведующая лабораторией мониторинга лесных экосистем Института мониторинга климатических и экологических систем СО РАН (Томск, Россия); dag@imces.ru

Авторы прочитали и одобрили окончательный вариант рукописи

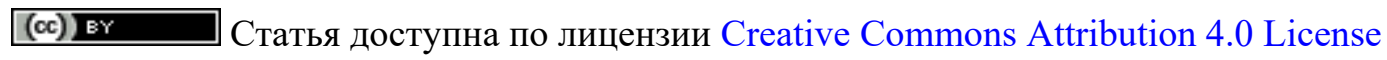




\section{FORMATION OF SOIL HUMUS PROFILE UNDER LONG-DERIVATIVE FORESTS ON THE VASYUGAN PLAIN (WEST SIBERIA, RUSSIA)}

\section{(c) 2018 N.V. Klimova, A.G. Dukarev}

Address: Institute of Monitoring of Climatic and Ecological Systems, Siberian Branch of the Russian Academy of Sciences, Russia.Email: klimnin@sibmail.com

Humus profile formation in southern Vasyugan plain is closely related to its parent rocks ranging from carbonaceous clays and heavy loams. Carbonates ensure slowing down of restoration cycles of the indigenous vegetation at the stage of grass deciduous forests (for more than one generation), because well developed grass cover dominated by bunch grasses impedes restoration of dark coniferous species. This gives an insular pattern to some features of climatic zonality due to different soil-vegetation relationship between zonal and successional derivative communities. Plant and soil cover determine local conditions for soil drainage and leaching.

In contrast to zonal forest communities with tree storey composed of dark conifers, growing on sod podsolic soils with residual humus horizons, under revegetating deciduous forests soil formation takes place under higher soil biological activity due to differing quantity and quality of plant matter input. The well drained areas under aspen and birch forest with understorey dominated by herbs and grasses (the most abundant species being Betula pubescens, Populus tremula, Carex macroura, Aegopodium podagraria, Calamagrostis obtusata, Equisetum pratense, Rubus saxatilis) are occupied by organic matter accumulating soddy podzolized soils with carbonate-containing layers close to the surface. In semihydromorphic and hydromorphic biotopes under smallreed aspen-birch forests (the most abundant species being Betula pubescens, Populus tremula, Calamagrostis phragmitoides Carex globularis, Equisetum sylvaticum, Filipendula ulmaria) organic matter accumulating soils with varying thickness of the humus/peat horizons are common. The species composition of such plant communities corresponds to the one typical for the southern taiga, but their production characteristics are closer to those common for the more southern communities of the northern forest-steppe with 3-5 t/ha (dry mass) of phytomass. Phytomass mineralization rate is higher, and leaves and grass decomposition products are less acidic as compared with zonal forests, where plant litter is rich in needles and mosses. As a result, organic matter accumulating soils under such communities developed some features, more common for their southern counterparts, distinguishing them from the soddy podzolic soils and making them more like the humus-accumulating soils in the northern forest-steppe. These soils have weak granulometric differentiation and well developed structure of the humus horizon. Humus content in quite high, reaching in the southernmost part of the soil area 6-8\% in humus accumulating horizons $(A U) 50 \mathrm{~cm}$ thick. The northernmost parts of the area see the decreased thickness of the dark humus horizon where the latter is substituted with brownish-gray $(A Y)$ horizon common for the taiga soils with 4-6\% humus content. Organic matter accumulating soil profiles were found to be contrasting in $\mathrm{pH}(\mathrm{H} 2 \mathrm{O})$, as the latter increased from 5.5-6.0 in layers immediately below the litter to the neutral values of 6.0-7.0 in humus horizons and 7.0-7.5 in subsoil horizons. High location of carbonates and solonetz properties of parent rock results in high (75-95\%) saturation of soil absorbing complex with basic elements, also preventing drastic degradation of humus profile, as only the topmost part of the humus horizon was found to be affected by acidic products of forest litter decomposition.

The relic part of the soil profile can be seen in all studied soils. The radiocarbon age of the relic horizons, as determined by humic acids, ranged 4,000-6,000 years. Humus quality reflects differences in humus horizon genesis. Contemporary horizon of soddy podzolised soils is formed due to climatic conditions of the southern taiga zone and has humic to fulvic acids ratio of 1.2-1.4 and low content of Ca-bound acids, while residual humus horizons were found to have increased humic acid content, decreased fulvic acids content of aggressive 1 and 1 a fractions, the highest ratio of humic to fulvic acid carbon of 1.8-2.1 and increased content of their Ca-bound fractions. These features, as well as a very low boundary of humus horizon indicate relic humus formation under more southern, i.e. forest-steppe, environmental conditions. The microbiomorph fraction of humus horizons was found to be dominated by plant detritus and phytoliths. The phytoliths assemblages of the contemporary and relic humus horizons were quite similar with notable absence of coniferous phytoliths. All these suggest that organic matter accumulating soils formation under different climatic conditions in late Holocene was related to phytocenoses similar to grassy deciduous forests.

The study revealed that both contemporary humus accumulation and relic humus preservation are negatively correlated with eluvial process rate. So successional dynamics of forest communities determines the pendulum nature of soil evolution. The stage of native dark coniferous forests is characterized by humus horizon degradation under acidic forest litter. The restoration stage of grassy birch forests accelerates humus accumulation and partial restoration of both contemporary and relic humus profiles, which is more explicit with the longer duration of this successional stage.

Key words: Vasyugan plain; long-derivative forests; contemporary and relic humus horizons; microbiomorphic analysis; humus fractional composition; soil evolution 
How to cite: Klimova N.V., Dukarev A.G. F Formation of soil humus profiles under long-derivative forests on the Vasyugan plain // The Journal of Soils and Environment. 2018. 1(4): 218-230. (in Russian with English abstract).

\section{REFERENCES}

1. Alexandrovskiy A.L. The evolution of the soils of the East European Plain in the Holocene. Moscow, Nauka Pbs., 1983, 150 p. (in Russian)

2. Bech I.A. Anthropogenic transformation of taiga forests. Novosibirsk, Nauka Pbs., 1992, 200 p. (in Russian)

3. Blyakharchuk T.A. History of Vegetation in the South-East of West Siberia in Holocene by the Data of Botanic and Spore-Pollen Analysis of Peat, Siberian Ecological Journal, 2000, $N^{\circ}$ 5, p. 659-668. (in Russian)

4. Gavrilov D.A. The Genesis of the Second Humus Horizon on the Plateau of Vasyugan Sloping Plain, Bulletin of Dokuchaev Soil Science Institute, 2016, V. 85, p. 3-19. doi: 10.19047/0136-1694-2016-85-5-19 (in Russian)

5. Gavrilov D.A., Loyko S.V., Lada N.Yu., Klimova N.V. Radio-Carbon Age of the Humus-Eluvial Part of the Polygenetic Soils in the Southern Taiga of Western Siberia. In book: Soil resources of Siberia: challenges of the XXI century. Proceedings of Russian Scientific Conference, Novosibirsk, 2017, p. 38-41. (in Russian)

6. Gadzhiev I.M. The Evolution of the Soils of the Taiga of Western Siberia. Novosibirsk, Nauka Pbs., 1982,278 p. (in Russian)

7. Golyeva A.A. Phytoliths and their Information Role in Natural and Archaeological Objects, Moscow, 2001, 200 p. (in Russian with English Summary)

8. Grishina L.A. Humus Formation and Soil Humus Condition. Moscow, MSU Publishing House, 1986,244 p. (in Russian)

9. Dyukarev A.G. Landscape-Dynamic Aspects of Soil Formation in the Taiga of Western Siberia. Tomsk, Scientific and technical literature, 2005, 284 p. (in Russian)

10. Dyukarev A.G., Pologova N.N. Soils with Complex Organic Profiles on the Vasyugan Plain, Eurasian Soil Science, 2011, V. 44, No 5, p. 480-492.

11. Dyukarev A.G., Pologova N.N., Mul'diyarov E.Ya. Meadow Soil Formation in the Subtaiga Zone of Western Siberia, Eurasian Soil Science, 2000, Vol. 33, No 9, p. 928-933.

12. Efremova T.T., Efremov S.P. Nature of Acidic Properties of Litter in Bog Birch Forests, Journal of Siberian Federal University. Biology, 2013, No 2, p. 205-219. (in Russian)

13. Efremova T.T., Efremov S.P., Avrova A.F. Correlation between the Morphogenetic Types of Litter and their Properties in Bog Birch Forests, Eurasian Soil Science, 2010, V. 43, No 8, p. 858-866.

14. Il'in R.S. Nature of the Narym Territory. In book: Materials on the Study of Siberia. Tomsk, 1930, Vol. 2, 344 p. (in Russian)

15. Kazantsev V.A. Pedohalogenesis Problems. Novosibirsk, Nauka Pbs., 1998, 280 p. (in Russian)

16. Kallas E.V., Kubrina E.V. The Specifics of the Humus Profile of the Meadow-Chernozem Soils of the Southern Taiga of Western Siberia, Tomsk State University Journal of Biology, 2008, $N^{\circ} 1$, p. 63-70. (in Russian)

17. Karavaeva N.A., Sokolova T.A., Tselishcheva L.K. Soil Formation Processes and the Evolution of Hydrogenic Soils of Subtaiga - Southern Taiga in the Holocene. In book: Soil Formation Processes and Soil Evolution. Moscow, Nauka Pbs., 1985, p. 139-201. (in Russian)

18. Soil classification of Russia / Authors and compilers: L.L. Shishov, V.D. Tonkonogov, I.I. Lebedeva, M.I. Gerasimov. Smolensk: Oykumena Pbs., 2004. 342 p. (in Russian)

19. Kozlovskaya L.S., Medvedeva V.M., P'yavchenko N.I. Dynamics of Organic Matter in the Process of Peat Formation. Leningrad, Nauka Pbs., 1978, 176 p. (in Russian)

20. Lashchinskyi N.N. Vegetation of the Salair Ridge. Novosibirsk, Geo, 2009, 263 p. (in Russian)

21. Lashchinskyi N.N., Korolyuk A.Yu. Syntaxonomy of Zonal Dark-Coniferous Forests of Southern Taiga of the West Siberian Plain and of Humid Low-Mountains of the Altai-Sayan Mountain Region, Vegetation of Russia, 2015, No 26, p. 85-107. (in Russian)

22. Ponomareva V.V., Plotnikova T.A. Guidelines for Determining the Content and Composition of Humus in Soils (Mineral and Peat). Leningrad, 1975, 105 p. (in Russian)

23. Ruzhanskyi V.V. Hydrogeological conditions. In book: Natural Conditions of Development between the Ob'Irtysh. Moscow, 1972, p. 32-36. (in Russian)

24. Titlyanova A.A., Shibareva S.V. Litter in Forests and Grasslands. Novosibirsk, Publishing House SB RAS, 2012, 137 p. (in Russian)

25. Ufimtseva K.A. Soils of the Southern Part of the Taiga Zone of the West Siberian Plain. Moscow, Kolos, 1974, 202 p. (in Russian)

26. Chramov A.A., Valutskii V.I. Forest and Swamp Phytocenoses of the Eastern Vasyugan Land. Novosibirsk, Nauka Pbs., 1977, 222 p. (in Russian) 


\section{About the authors:}

Klimova Nina V. - Junior Research, Institute of Monitoring of Climatic and Ecological Systems, Siberian Branch of the Russian Academy of Sciences, Tomsk, Russia; klimnin@sibmail.com

Dukarev Anatolyi G. - Doctor of Geography Sciences., Head of Laboratory, Institute of Monitoring of Climatic and Ecological Systems, Siberian Branch of the Russian Academy of Sciences, Tomsk, Russia;dag@imces.ru

The authors read and approved the final manuscript

(c) $\mathbf{E Y}$ The article are available under Creative Commons Attribution 4.0 License 